\title{
A study on the key factors of suitability for performance-based logistics using a multi-criteria decision-making method ${ }^{*}$
}

\author{
Inseob Hong $^{* *} \cdot$ Sukjae Jeong ${ }^{* * *}$
}

\begin{abstract}
In response to worldwide changes in logistics, the Korean Ministry of Defense has introduced performance-based logistics (PBL) to improve cost-effectiveness and availability in sustaining their weapon system. Thus, the procurement of reduced parts and the maintenance period improve the availability of equipment, and the reduction of the inventory level lowers overall logistics costs.

Based on these achievements, the Ministry of National Defense is pursuing a policy to expand the PBL project. However, the criteria for selecting equipment subject to the application are ambiguous. Therefore, it is difficult to expand to all areas. Consequently, this paper aims to present the criteria for selecting future PBL projects by providing objective judgment factors and quantifying
\end{abstract}

(@) (1) This work is licensed under a Creative Commons Attribution 4.0 International License.

* The present research has been conducted by the Research Grant of Kwangwoon University in 2019.

** Kwangwoon University, Defense Acquisition Program, Ph.D. Candidate(Republic of Korea Air Force Headquarters. Logistics Command. Lieutenant Colonel), inseobh@gmail.com

*** Kwangwoon University, College of Business, Professor, sjjeong@kw.ac.kr, orcid 0000-0001-7081-7567 
the suitable equipment for the application of PBL. For this, a delphi-analytic approach was used to derive the key factors for performance-based logistics experts, and the survey was carried out twice. A total of eight key factors were derived from the survey analysis. Subsequently, a third survey was conducted to determine the level of assessment for each key factor and to prioritize each card according to this conjoint method to determine the utility of each factor according to its level. Through this, a performance-based suitability model that combines the weighting of key factors with the level of each factor was presented.

This study is meaningful in that it selected key factors for determining the suitability of performance-based military applications based on objective data. Further, their reference values can be comprehensively determined by calculating the utility of each factor level.

Keywords : performance-based logistics, equipment availability, spares procurement period, delphi-analysis, conjoint-analysis 


\section{I. 서론}

우리 군은 21세기 전략 환경과 미래전에 부합할 수 있는 국방역량과 태세를 갖추고 '정예화된 선 진강군'을 육성하기 위해 국방개혁 기본계획(2014 2030)을 수립하였는데, 이 기본계획에 따라 군 수분야에서는 '군수 운영혁신 및 민간자원 활용 확대’를 중점과제로 추진하고 있으며, 그 과제의 일 환으로 강도 높은 경영 효율화를 달성하기 위하여 국방부는 2008년 “성과기반군수지원 제도” 도입 을 결정하였으며 2010년 공군 KT/A-1 항공기, 육군 군단급 무인기, 해군 홍상어 미사일에 시범 적 용한 이후 항공무기체계를 중심으로 확대하여 왔다. 2020년 현재 우리 군의 성과기반군수지원 사업 은 항공무기체계뿐만 아니라 지상 및 해상무기체계까지 확대하고 있다. 특히, F- $15 \mathrm{~K}, \mathrm{~T}-50$, $\mathrm{KT} / \mathrm{A}-1$ 항공기 성과기반군수지원 사업은 사업을 통해 장비 가동률 향상, 비용 절감 등의 성과가 가시적으로 달성되어 5년 차 계약기간 만료 후 재계약하여 운영 중에 있다. 이렇듯 국방부는 기존 사업의 성과를 바탕으로 성과기반 군수지원 사업을 전군에 확대하고 있으며, 나아가 현 정부 출범 시 성과기반군수지원 사업확대 정책을 100 대 국정과제의 세부과제로 반영하여, 항공장비 위주의 초기 사업을 전군으로 확대하고 있는 중이다. 특히 지상 - 해상무기체계에 적용할 성과기반군수지 원 사업을 신규로 발굴하기 위해서는 어떠한 사업이 기존의 군수 지원방법보다 효과적인지를 판단 할 수 있는 기준이 마련되어 있어야 하나, 현 국방부 훈령에는 정성적인 기준만이 수록되어 있어 실무부서에서 활용할 수 있는 구체적이고 정량적 기준이 필요하다. 이에 본 연구에서는 PBL 선정 을 위한 핵심적인 판단 요소와 각 요소별 정량적인 수준을 제시하여 각 군의 신규사업 발굴을 위한 객관적인 기준을 제시하였다.

본 연구는 크게 세 부분으로 구성된다. 첫째, 기존 연구를 고찰하여 성과기반군수지원 제도의 개 념, 적용목적, 계약방법 등을 소개하였고, 둘째, 한국군 성과기반군수지원 제도 확대를 위해 성과기 반군수 적용 적합장비 판단기준의 객관적 분석과 정량화가 필요하다는 점을 제시하고 이에 따른 연구방향을 제시하였다. 셋째, 도출된 연구방향에 따라 기존에 성과기반군수지원 적용 적합장비 기 준에 대한 판단요소를 전문가의 의견을 수렴하는 델파이 분석방법으로 식별하였고, 그중에 핵심적 인 요인을 2 차 설문과 타당도 검증을 통해 선별하였다. 넷째, 판단 요인별 수준에 따른 효용도를 컨조인트 기법으로 분석하여 요소별 수준에 따른 점수를 토대로 대상 장비별 적용 수준을 평가하 는 수치적 모형을 제안함으로써 각 군의 성과기반군수지원 대상장비 선정의 객관적인 근거를 제시 하고자 하였다. 본 연구의 최종적인 목적은 각 군에서 성과기반군수(PBL) 사업을 신규로 추진할 때, 적용하고자 하는 장비가 성과기반군수(PBL) 제도에 적합한 장비인지 판단할 수 있는 합리적인 기준을 제공함에 있다. 


\section{ㅍ. 관련 연구}

\section{1 성과기반군수지원 소개}

\subsection{1 개념의 태동}

성과기반군수지원(PBL)은 1998년 미 국방성의 “군수지원혁신계획”에 의거 군 병력 및 시설축소 를 통한 예산절감을 위해 민간자원을 활용한 방법으로 1990년대부터 적용해 온 기존의 계약자군수 지원의 단점을 보완하는 총수명주기관리 관점에서 개념화되었으며, 2001년 국방검토보고서(QDR) 와 DoD Policy for Fiscal Year 2003을 통해 방위산업 관련 업체에 적용함으로서 본격적으로 시작 되었다.1) 미 국방성 최초의 사업은 1999년 F-117 Nighthawk 스텔스 항공기에 적용되어 미군이 필 요로 하는 보급지원 안정성과 가용성을 제공하고, 혁신적인 비용절감책을 제공하는 것이었다(미, DOD).

\subsection{2 성과기반군수지원 제도 개념}

성과기반군수지원(PBL)은 “군수품의 안정적인 가동률 보장을 위해 소요군은 가동률, 조달기간 등 성과측정지표를 제시하고 계약상대방은 장기계약 또는 장기계속계약으로 군수지원요소의 일부 또는 전부를 제공하여 그 성과에 따라 대가를 차등 지급하는 제도”를 말한다.2) 성과기반군수지원 은 넓은 의미로는 포괄적인 업무범위에 대해 장기간에 걸친을 체결하고 민 · 군 협의 하에 성과측 정지표와 목표를 설정하는 군수분야의 민 · 군 협력을 의미하며, 좁은 의미로는 계약업체에 의한 군수지원, 장기(계속)계약, 성과측정 및 평가의 합이라 정의될 수 있다.

원론적인 성과기반군수지원 개념 및 목적에 의하면 성과기반군수지원(PBL)은 적용대상(물)에 따라 수준(민, 군)을 차등적으로 적용할 수 있다. 적용대상은 수리부속 조달, 보급, 정비, 기술지원 등을 기능별로 적용할 수 있으며, 완성장비, 시스템, 구성품, 수리부속 등으로 대상을 구별하여 적 용할 수 있다. 국외사례에 의하면 군과 계약업체의 $\mathrm{PBL}$ 지원 제휴관계 정도에 따라 군 중심의 $\mathrm{PBL}$ 지원과 업체 중심의 $\mathrm{PBL}$ 지원으로 구분되고 다양한 유형이 적용되는데, 전체체계 지원협력(TSSP: Total System Support Partnership), 업체협력(Industry Partnering), 서비스 수준의 협약(Service Level Agreement), 정부/업체 제휴(Government/Industry Partnering), 성과기반 신속 군수 지원 (PALS; Performance-based Agile Logistics Support), 소규모 저장품목 성과기반군수지원 (PBL-MSP; Mini-Stock Point), 주공급자 지원(PVS; Prime Vendor Support), 계약자 군수지원

1) 국방부 성과기반군수지원 길라잡이(공개판) 2016

2) 국방부 훈령 제2061호, 성과기반군수지원 훈령(2017.8.17.) 
(CLS; Contractor Logistics Support), 계약업체 운송 체계(CDS; Contractor Delivery System), 공 급자 직접 배송(DVD; Direct Vendor Delivery) 등의 다양한 형태와 이름으로 적용되고 있다.3)

\section{1 .3 성과기반군수지원 적용 목적4)}

r성과기반군수지원 훈령」제 1 조는 r군수품관리법 시행령」제 12 조의 3 제 4 항, r방위사업법 시행령」 제 28 조 제 4 항 및 제 61 조 제 1 항 제 10 호에 따라 전투준비태세 보장, 총소유비용 절감, 국가정비역량 강화를 위한 성과기반군수지원의 수행과 관련된 업무의 기본절차를 규정하고 지침을 제공함을 목 적으로 한다. 즉, 성과기반군수지원 적용 시 군은 다음의 세 가지 효과를 기대할 수 있다. 첫째, 기 존 수리 부속 조달 및 정비 방식보다 향상된 성과달성을 통해 전투준비태세 보장에 기여할 수 있다. 둘째, 기존 수리 부속 조달 및 정비 방식보다 군수지원 반응시간 감소로 장비 운영 유지 비용 절감으로 총소유 비용절감에 기여한다. 셋째, 성과기반군수지원 제도 적용을 통해 수요군의 자체 수리 능력을 포함한 역량 강화의 기회로 활용할 수 있다.

\subsection{4 성과기반계약}

성과기반계약은 성과기반군수지원을 적용하기 위한 계약의 방법을 말하며, 다음과 같은 특성을 가진다. 성과기반계약은 「방위사업법 시행령」(대통령령 제21596호, 2009.7.1, 일부개정) 제61조(계 약의 종류 - 내용 및 범위 등)에서 '계약을 체결하는 때에 특정한 성과의 달성을 요구하고 계약 이 행 후 그 성과에 따라 대가를 차등 지급하려는 경우로 명시하고 있다.

성과기반계약이란 무기체계에 있어 최상의 전투준비태세 유지와 총소유비용의 최소화를 달성할 수 있도록 설계된 군수 지원 성과를 장기간에 걸쳐 구매하는 계약으로 전투부대 요구사항에 기초 하여 업체가 제공하여야 할 성과목표를 계약자와 협의에 의해 결정한 후 계량화한 성과지표 (Metrics)에 따라 지원성과(Performance Outcome)를 평가하고 그 결과에 따라 적절한 성과 보상 을 제공함으로써 성과관리(Performance Management) 실시하는 것으로 군수 지원에 있어 군은 업 체에 일정한 권한과 책임을 부여함으로써 각종 부담을 감소시킬 수 있다.

기존 군수지원에서는 물품 및 용역을 주로 단가계약의 형태로 구매하는 것인데 이러한 방식의 문제점은 군에서 구매하는 품목, 양, 시기를 결정함에 따라 업체의 성능개량, 연구개발 등에 대한 투자 유인의 제한과, 보급능력에 중점을 둔 재고관리로 군수지원에 투자되는 비용과 무기체계 준비 태세의 연관성 저하로 효율적인 군수지원의 제한을 초래할 수 있다.

3) 우제웅, 강한구, 권남현, 진아연, "성과기반군수지원(PBL) 제도의 효율적 추진방안" 국방부 연구과제, 한국국방연구원 (KIDA), Oct. 2014

4) 국방부 성과기반군수지원 길라잡이(공개판) 2016 
반면, 성과기반계약은 업체로부터 군수 지원 성과를 구매하는 것으로 계약업체는 지속적인 이윤 을 추구함과 동시에 원가를 절감하기 위한 노력을 하고, 그 결과 무기체계의 전투 준비태세를 향상 하고 총 소유 비용의 절감에 기여할 수 있다. 즉, 개별 부품이나 수리 부속 혹은 용역 등을 구매하 지 않고 군수지원 성과(Performance Outcomes)를 구매하여, 업체 이익 창출을 위한 효율적인 군수 지원을 유도하고, 업체의 성능개량, 품질관리, 보급망 관리 등의 동기부여가 가능하며, 군수 지원 성과에 따라 비용을 차등 지불하여 업체의 군수지원 성과 증대가 가능하다.

성과기반계약은 경쟁계약이나 수의계약으로 체결하며, 무기체계 등의 계약에 있어 특수한 설 비 - 기술 - 성능 - 품질 - 용역이 요구되는 한국 방위산업 시장 특성을 감안할 때 수의계약이 일반 적이다.

\subsection{5 성과기반군수 적용 대상사업 선정5)}

국방부 성과기반군수지원 훈령에 따라 소요군은 $\mathrm{PBL}$ 적용 대상 사업 선정에 있어 다음과 같은 사항을 고려하되 제반 사항을 종합적으로 판단하여 검토하도록 명시하고 있다.

- 정비 신뢰도가 낮아 전투부대 요구들 미충족하는 장비

- 긴요한 수리 부속 대기시간이 장기화되고 있거나, 수리 부속 진부화 속도가 빠른 장비

- 수리 난이도·외주정비 소요가 증대되는 고가의 전자 정밀 장비

- 국가급 자산으로 운용되는 장비

- 고가의 수리 부속 소요가 증가하는 모듈화된 구성품으로 구성된 장비

- 정비유지비 소요가 많은 고가의 다종 소량장비

- 잔여 수명주기가 비교적 장기간 남은 장비

- 업체 기반체계 활용 시 지원의 효율성이 높은 장비 및 물자

\section{III. 연구방법}

관련 연구를 통해 성과기반군수 적용 대상 사업 선정 시 정성적인 고려사항은 국방부 훈령에 이 미 반영되어 있으나, 위 기준에 대한 정량적인 분석이나 검증은 이루어지지 않은 상태이며, 각 군이 신규로 도입하거나 운용 중인 장비에 대해 성과기반군수를 적용할지 여부를 판단을 하는데 이 기 준을 적용하는 것에 애로를 겪고 있다. 이에 본 연구에서는 우선 전문가 의견을 수렴한 델파이 분 석을 통해 어떠한 요소가 성과기반군수를 적용하는 데 적합한 핵심 요소인지 식별하고, 식별된 핵 심 요소 수준을 설정하여 그 수준별 효용도를 선택기반 컨조인트 기법을 통해 분석하였다.

5) 국방부 훈령 제2061호, 성과기반군수지원 훈령(2017.8.17.) 


\section{1 자료 수집}

본 연구에서는 성과기반군수지원 적용에 적합한 요인을 도출하기 위하여 국방부 훈령 및 각종 연구와 국방부 지침에 나와있는 요인들을 분석하였다. 이중에 <표 $1,2>$ 의 2016년 국방부에서 제 시한 성과기반군수(PBL) 적용 대상 장비 분류기준을 기준으로 하여, 전문가 설문을 토대로 추가 요인을 식별하였다.

<표 1> 국방부 PBL 적용 판단 기준

\begin{tabular}{|c|c|c|c|c|c|c|c|}
\hline \multirow{2}{*}{ 수준 } & \multicolumn{3}{|c|}{ 장비 가동률(보급지연불가동률) } & \multirow{2}{*}{$\begin{array}{c}\text { 수리부속 조달기간 } \\
\text { 또는 정비기간 } \\
\end{array}$} & \multirow{2}{*}{$\begin{array}{c}\text { 5년간 평균 } \\
\text { 부품단가 상승률 }\end{array}$} & \multirow{2}{*}{$\begin{array}{c}\text { 장비 } \\
\text { 잔여수명 } \\
\end{array}$} & \multirow{2}{*}{ 점수 } \\
\hline & 지상 & 함정 & 항공 & & & & \\
\hline Level 1 & $\begin{array}{l}98 \% \text { 이상 } \\
\text { (1\%미만) }\end{array}$ & $\begin{array}{l}75 \% \text { 이상 } \\
\text { (12\%미만) }\end{array}$ & $\begin{array}{l}\text { 85\%이상 } \\
\text { (3\%미만) }\end{array}$ & 30일 미만 & $3 \%$ 미만 & 5년 미만 & 0 \\
\hline Level 2 & $\begin{array}{l}94 \sim 98 \% \\
(1 \sim 2 \%)\end{array}$ & $\begin{array}{c}70 \sim 75 \% \\
(12 \sim 15 \%)\end{array}$ & $\begin{array}{l}80 \sim 85 \% \\
(3 \sim 5 \%)\end{array}$ & $\begin{array}{l}\text { 30일 이상 } \\
90 \text { 일 미만 }\end{array}$ & $\begin{array}{l}3 \% \text { 이상 } \\
5 \% \text { 미만 }\end{array}$ & $\begin{array}{l}\text { 5년 이상 } \\
7 \text { 년 미만 }\end{array}$ & 1 \\
\hline Level 3 & $\begin{array}{l}90 \sim 94 \% \\
(1 \sim 2 \%) \\
\end{array}$ & $\begin{array}{c}65 \sim 70 \% \\
(15 \sim 17 \%)\end{array}$ & $\begin{array}{l}75 \sim 80 \% \\
(5 \sim 7 \%)\end{array}$ & $\begin{array}{l}\text { 90일 이상 } \\
150 \text { 일 미만 }\end{array}$ & $\begin{array}{l}5 \% \text { 이상 } \\
10 \% \text { 미만 }\end{array}$ & $\begin{array}{c}\text { 7년 이상 } \\
10 \text { 년 미만 }\end{array}$ & 2 \\
\hline Level 4 & $\begin{array}{l}85 \sim 90 \% \\
(5 \sim 7 \%)\end{array}$ & $\begin{array}{c}60 \sim 65 \% \\
(17 \sim 20 \%)\end{array}$ & $\begin{array}{l}70 \sim 75 \% \\
(7 \sim 10 \%)\end{array}$ & $\begin{array}{l}150 \text { 일 이상 } \\
200 \text { 일 미만 }\end{array}$ & $\begin{array}{l}10 \% \text { 이상 } \\
20 \% \text { 미만 }\end{array}$ & $\begin{array}{l}10 \text { 년 이상 } \\
15 \text { 년 미만 }\end{array}$ & 3 \\
\hline Level 5 & $\begin{array}{l}80 \sim 85 \% \\
(7 \sim 10 \%)\end{array}$ & $\begin{array}{c}55 \sim 60 \% \\
(20 \sim 22 \%)\end{array}$ & $\begin{array}{c}65 \sim 70 \% \\
(10 \sim 15 \%)\end{array}$ & $\begin{array}{l}200 \text { 일 이상 } \\
250 \text { 일 미만 }\end{array}$ & $\begin{array}{l}20 \% \text { 이상 } \\
30 \% \text { 미만 }\end{array}$ & $\begin{array}{l}\text { 15년 이상 } \\
\text { 20년 미만 }\end{array}$ & 5 \\
\hline Level 6 & $\begin{array}{c}75 \sim 80 \% \\
(10 \sim 13 \%)\end{array}$ & $\begin{array}{l}50 \sim 55 \% \\
(22 \sim 25 \%)\end{array}$ & $\begin{array}{c}60 \sim 65 \% \\
(15 \sim 20 \%)\end{array}$ & $\begin{array}{l}250 \text { 일 이상 } \\
365 \text { 일 미만 }\end{array}$ & $\begin{array}{l}30 \% \text { 이상 } \\
40 \% \text { 미만 }\end{array}$ & $\begin{array}{l}\text { 20년 이상 } \\
\text { 25년 미만 }\end{array}$ & 7 \\
\hline Level 7 & $\begin{array}{c}75 \% \text { 미만 } \\
\text { (13\%이상) }\end{array}$ & $\begin{array}{l}75 \% \text { 이상 } \\
\text { (12\%미만) }\end{array}$ & $\begin{array}{l}\text { 85\%이상 } \\
\text { (3\%미만) }\end{array}$ & 365일 이상 & $40 \%$ 이상 & 25년 이상 & 10 \\
\hline $\begin{array}{l}\mathrm{PBL} \\
\text { 적용조건 } \\
\text { 및 } \\
\text { 요소별 } \\
\text { 고려요소 }\end{array}$ & \multicolumn{7}{|c|}{$\begin{array}{l}\text { - 장비가동률: 장비별 목표가동률 적용(전투준비태세업무 훈령 적용) } \\
\text { - 보급지연으로 인한 불가동률: 총 불가동률의 } 50 \% \text { 수준으로 설정 } \\
\text { - 조달기간/정비기간: } 120 \text { 일이상 소요시(장비별 게약대상 품목 평균 조달기간 반영) } \\
\text { - 단가상승률: } 5 \text { 년간 } 20 \% \text { 이상시(KIDA 심층평가 결과) } \\
\text { / 신규장비는 Level } 1 \text { 적용, } 5 \text { 년 미만은 Level } 4 \text { 적용 } \\
\text { - 잔여수명: } 10 \text { 년 이상시(PBL 기본계약 } 5 \text { 년 및 } 2 \text { 차계약 고려) }\end{array}$} \\
\hline
\end{tabular}


<표 2> 국방부 $\mathrm{PBL}$ 적용 판단 점수

\begin{tabular}{c|c|c|c}
\hline 구분 & 평균 Level 5 이상 & 평균 Level 4 & 평균 Level 3 미만 \\
\hline \hline 총 점수 기준 & 20점 이상 & 12점 $~ 19$ 점 & 11점 이하 \\
\hline 검토순위 & 우선 검토대상 & 차 순위 검토대상 & 적용 보류 \\
\hline
\end{tabular}

\section{2 델파이 분석을 통한 지표별 가중치 및 내용 타당도 분석}

설문은 <표 3>과 같이 현재 또는 과거에 성과기반군수 관련 정책을 수립하는데 관여하였거나, 사업관리 및 계약업무를 직간접적으로 이행한 실무자, 성과기반군수지원 관련 연구를 수행한 $\mathrm{KIDA}$ 연구원 등을 대상으로 시행하여 연구의 신뢰성을 확보하였다. 설문조사 집단 중 소요군은 공군만을 설문하였는데, 주로 항공 장비를 중심으로 성과기반군수(PBL) 사업이 진행되었기 때문이 며, 이에 따라 본 연구 결과는 항공 장비에 특화되어 분석되었다.

<표 3> 델파이 설문조사 집단구성(일부 중복 응답 포함)

\begin{tabular}{c|c|c|c|c|c}
\hline 구 분 & 국방부 & 방위사업청 & 공군 & KIDA & 합계 \\
\hline \hline 정책결정 & 3 & & 2 & 1 & 6 \\
\hline 사업관리 & & 2 & 5 & & 7 \\
\hline 계약관리 & 1 & 2 & 4 & & 7 \\
\hline 정책지원 & & & 4 & 1 & 5 \\
\hline 합계 & 4 & 4 & 15 & 2 & 25 \\
\hline
\end{tabular}

설문은 3 차에 걸쳐서 실시하였으며, 1 차 설문 시 기존 국방부 성과기반군수지원 판단 기준과 연 구자가 추가한 몇 가지 요인을 제시한 후 응답자가 추가할 필요가 있다고 생각하는 지표를 포함하 도록 하는 개방형 질문을 실시하였다. 그 결과 최초 제시된 6 개의 지표 외에 10 개의 지표가 <표 4> 와 같이 식별되었다.

<표 4> 1차 델파이 설문조사

\begin{tabular}{c|c}
\hline 기존 국방부 판단기준(지표) & 추가 지표 \\
장비가동률 & 신규도입 여부 \\
보급지연 불가동률 & 장비가격(단가) \\
수리부속 조달기간 & 군내 정비능력 확보여부 \\
외주정비 소요기간 & 업체 참여의지 및 수행능력 \\
부품단가 상승률 & 예산운용 적합성(예산절감 기대효과) \\
장비 잔여수명 & 동류전용율 \\
장비운영 대수 & 군내 창급정비능력 확보여부 \\
& 창급정비기술 확보 가능성 \\
& 임무중요도 \\
\hline
\end{tabular}


2 차 설문조사는 1 차 설문조사 결과를 반영하여 선별한 지표의 중요도(가중치)와 지표별 내용 적 합도(CVR)을 구하기 위해 실시하였으며, 전문가들에 의해 제시된 여러 지표 중 다수가 공감하는 핵심적인 지표와 그렇지 않은 지표를 Lawshe(1975)에 의해 제안된 내용적합도 CVR(Content Validity Ratio)로 평가하여 선별하는 과정을 거쳤으며, 그 공식은 아래와 같다.

$$
C V R=\frac{n_{e}-(N / 2)}{N / 2}
$$

$\mathrm{CVR}=$ content validity ratio; $\mathrm{n}_{\mathrm{e}}=$ Numbers indicating an item 'essential' ; N= Number of Panel members

\begin{tabular}{c|c}
\hline \multicolumn{2}{c}{$\begin{array}{c}\text { Minimum valuess of } \text { CVR } \\
\text { One Tailed Test, } P=.05\end{array}$} \\
\hline \hline No. of Panelists & Minium Value \\
\hline 9 & 0.75 \\
10 & 0.78 \\
11 & 0.62 \\
12 & 0.59 \\
13 & 0.56 \\
14 & 0.54 \\
15 & 0.51 \\
20 & 0.49 \\
25 & 0.42 \\
30 & 0.37 \\
35 & 0.33 \\
40 & 0.31 \\
\hline
\end{tabular}

2 차 설문을 위해 1 차 설문을 토대로 식별된 지표를 재정리하면 아래 <표 $5>$ 와 같다.

<표 5> 델파이 1차 설문조사 결과

\begin{tabular}{|c|c|c|c|}
\hline 번호 & 판단요인(지표) & 지표설명 & 그룹 \\
\hline 1 & 장비가동률(FMC, $\mathrm{MC})$ & 장비 보유 대비 가동대수가 목표를 하회하는가? & \multirow{4}{*}{$\begin{array}{l}\text { 운용적 } \\
\text { 측면 }\end{array}$} \\
\hline 2 & 보급지연 불가동률 & 부품지원불가로 발생한 불가동이 목표를 하회하는가? & \\
\hline 3 & 업체 참여의지 및 능력 & PBL계약을 이행할 의지와 능력이 있는 업체가 있는가? & \\
\hline 4 & 예산운용 적합성 & 예산 절감효과를 기대할 수 있는가? & \\
\hline 5 & 부품 조달기간 & 부품 청구/확보시까지 걸린 시간이 일정수준 이상인가? & \multirow{3}{*}{$\begin{array}{l}\text { 공급망 } \\
\text { 관리 } \\
\text { 측면 }\end{array}$} \\
\hline 6 & 부품단가 상승률 & 최근 5년간 구매단가 상승률이 일정수준 이상인가? & \\
\hline 7 & 부품 재고 보유여부 & 대상장비의 보유중인 부품이 일정수준 이상인가? & \\
\hline
\end{tabular}




\begin{tabular}{c|c|l|l}
\hline 8 & 동류전용률 & 타장비 부품 탈거/장착 비율이 일정수준 이상인가? & \\
\hline 9 & 외주정비 소요기간 & 고장 부품 외주정비 소요기간이 일정수준 이상인가? & \multirow{2}{*}{ 정비 } \\
\hline 10 & 군내 정비능력 확보여부 & 정비 기반시설 및 정비장비, 정비사 확보가 필요한가? & \multirow{2}{*}{ 오소 } \\
\hline 11 & 창급 정비기술 확보여부 & 군내에 창급(완전분해) 정비능력을 구비할 수 있는가? & \\
\hline 12 & 장비 잔여수명 & 설계수명에서 운용기간을 제외한 기간이 어느정도인가? & \\
\cline { 1 - 3 } 13 & 장비가격(잔존가치) & 장비의 도입가격 또는 현가치가 일정수준 이상인가? \\
\cline { 1 - 2 } 14 & 신규장비 여부 & PBL적용시 신규장비 여부가 판단 기준이 되는가? & \multirow{2}{*}{ 속성 } \\
\hline 15 & 장비운영 대수 & 현재 운영(예정)된 장비 운영대수는 어느정도인가? & \\
\hline & 임무 기여도 & 전시 임무수행에 미치는 영향이 큰 장비인가? &
\end{tabular}

2차 델파이 설문으로 성과기반군수 적용이 적합한 장비의 판단 요소로 기존 운영 중인 장비와 신규 장비가 다른 결과를 나타낼 것으로 가정하여 설문을 구분하여 실시하였다. 아래의 <표 $6>$ 은 이렇게 제시된 지표별 중요도(가중치)와 적합도를 설문한 결과를 보여주고 있다.

<표 6> 델파이 2차 설문조사 결과

\begin{tabular}{|c|c|c|c|c|c|c|c|c|c|c|}
\hline \multirow[b]{2}{*}{ 번호 } & \multirow[b]{2}{*}{ 지표명 } & \multicolumn{3}{|c|}{ 종 합 } & \multicolumn{3}{|c|}{ 신규장비 } & \multicolumn{3}{|c|}{ 운영중인 장비 } \\
\hline & & $\begin{array}{l}\text { 점수 } \\
\text { 평균 }\end{array}$ & $\begin{array}{l}\text { 적합도 } \\
0.29 \uparrow\end{array}$ & $\begin{array}{l}\text { 지표 } \\
\text { 채택 }\end{array}$ & $\begin{array}{l}\text { 점수 } \\
\text { 평균 }\end{array}$ & $\begin{array}{l}\text { 적합도 } \\
0.42 \uparrow\end{array}$ & $\begin{array}{l}\text { 지표 } \\
\text { 채택 }\end{array}$ & $\begin{array}{l}\text { 점수 } \\
\text { 평균 }\end{array}$ & $\begin{array}{l}\text { 적합도 } \\
0.42 \uparrow\end{array}$ & $\begin{array}{l}\text { 지표 } \\
\text { 채택 }\end{array}$ \\
\hline 1 & 장비가동률(FMC, $\mathrm{MC})$ & 4.53 & 0.75 & 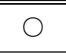 & 4.30 & 0.6 & 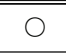 & 4.75 & 1.00 & 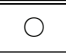 \\
\hline 2 & 보급지연 불가동률 & 4.40 & 0.80 & 0 & 4.30 & 0.6 & O & 4.50 & 0.90 & O \\
\hline 3 & 업체 참여의지 및 능력 & 4.15 & 0.75 & O & 4.15 & 0.80 & $\bigcirc$ & 4.15 & 0.80 & $\bigcirc$ \\
\hline 4 & 예산운용 적합성 & 4.08 & 0.65 & O & 4.05 & 0.80 & $\bigcirc$ & 4.10 & 0.80 & $\bigcirc$ \\
\hline 5 & 부품 조달기간 & 3.78 & 0.50 & O & 3.60 & 0.50 & 0 & 3.95 & 0.80 & 0 \\
\hline 6 & 부품단가 상승률 & 3.08 & -0.30 & & 3.00 & 0.10 & & 3.15 & 0.20 & \\
\hline 7 & 부품 재고 보유여부 & 3.28 & -0.05 & & 3.15 & 0.00 & & 3.40 & 0.20 & \\
\hline 8 & 동류전용률 & 3.13 & -0.25 & & 2.90 & 0.00 & & 3.35 & 0.20 & \\
\hline 9 & 외주정비 소요기간 & 3.50 & 0.05 & O & 3.35 & 0.20 & & 3.65 & 0.50 & $\bigcirc$ \\
\hline 10 & 군내 정비능력 확보여부 & 3.60 & 0.20 & & 3.70 & 0.40 & & 3.50 & 0.40 & \\
\hline 11 & 창급 정비기술 확보여부 & 3.73 & 0.30 & O & 3.85 & 0.50 & 0 & 3.60 & 0.50 & 0 \\
\hline 12 & 장비 잔여수명 & 3.13 & -0.20 & & 3.10 & 0.00 & & 3.15 & 0.10 & \\
\hline 13 & 장비가격(잔존가치) & 2.68 & -0.55 & & 2.85 & 0.20 & & 2.50 & -0.40 & \\
\hline 14 & 신규장비 여부 & 2.35 & -0.90 & & 2.45 & -0.50 & & 2.25 & -0.60 & \\
\hline 15 & 장비운영 대수 & 3.35 & 0.00 & & 3.55 & 0.40 & & 3.15 & 0.20 & \\
\hline 16 & 임무 기여도 & 3.80 & 0.30 & 0 & 3.85 & 0.60 & 0 & 3.75 & 0.50 & 0 \\
\hline
\end{tabular}

* 점수는 5점 만점, 종합 적합도 $(\mathrm{CVR})$ 0.29이상 채택

설문 종합 결과 7 개의 지표가 성과기반군수(PBL) 적용 판단 요인(지표)로 적합한 것으로 나타났 으나, 이중 '외주정비 소요 기간'은 운영 중인 장비에 있어서 적합도가 높은 지표로 나타나 포함하 
였으며, 이에 따라 총 8개의 지표를 적합한 지표로 최종 선정하였다.

분석 전 가정 사항으로 기존 운영 중인 장비와 신규 장비는 성과기반군수(PBL) 적용 적합 판단 요인이 다른 결과를 나타낼 것으로 예측하였으나, 적합도 분석 결과 채택된 지표에서는 신규 장비 일 경우 외주정비 소요 기간이 채택되지 않은 것을 제외하면 동일한 결과를 나타내었다. 또한, 성과 기반군수(PBL) 적용 여부를 판단하는 요인에 대한 우선 순위에 있어서도 유의미한 차이는 발견되 지 않았다.

그러나, 적합도에 있어서는 다음과 같은 차이점이 발견되었는데 운영 중인 장비는 현 장비 가동 률 및 보급 불가동률이 성과기반군수(PBL) 적용 판단 시 가장 적합한 요인이고, 그 다음으로 업체 의 참여 의지 및 능력과 예산 운용 적합성, 부품 조달 기간이 같은 수준으로 나타났으나, 신규 장비 는 업체의 참여 의지 및 능력과 예산운용 적합성이 가장 적합도가 높은 요인으로 식별되었고, 이어 서 장비 가동률, 보급 지연 불가동률, 임무 기여도가 같은 수준으로 적합한 요인으로 나타났다. 즉, 운용 중인 장비는 현재의 가동률이 가장 적합한 요인이나, 신규로 도입될 장비는 가동률보다는 예 산절감 기대나 업체의 참여 의지 및 능력이 더 적합하다고 판단하였는데, 이는 신규 장비의 경우 예산편성을 논리 확보와 업체와 계약 가능성이 사업의 성패를 결정하기 때문일 것이다.

결론적으로 델파이 설문을 통해 선정된 최종 선정지표는 <표 $7>$ 과 같으며, 현 국방부 판단지표 대비 유지 4건, 추가 4건, 삭제 3 건으로 최종 8개의 지표가 선정되었다.

<표 7> 최종 선정된 핵심요인(지표) 및 중요도(가중치)

\begin{tabular}{c|c|c|c|c}
\hline 번호 & 국방부 판단지표 & 2차 설문지표 & 최종 선정지표 & 국방부 지표 대비 \\
\hline \hline 1 & 장비가동률(FMC, $\mathrm{MC})$ & 장비가동률(FMC, $\mathrm{MC})$ & 장비가동률(FMC, $\mathrm{MC})$ & 유지 \\
\hline 2 & 보급지연 불가동률 & 보급지연 불가동률 & 보급지연 불가동률 & 유지 \\
\hline 3 & & 업체 참여의지 및 능력 & 업체 참여의지 및 능력 & 추가 \\
\hline 4 & & 예산운용 적합성 & 예산운용 적합성 & 추가 \\
\hline 5 & 부품 조달기간 & 부품 조달기간 & 부품 조달기간 & 유지 \\
\hline 6 & 부품단가 상승률 & 부품단가 상승률 & & 삭제 \\
\hline 7 & & 부품 재고 보유여부 & & \\
\hline 8 & & 동류전용률 & & 유지 \\
\hline 9 & 외주정비 소요기간 & 외주정비 소요기간 & 외주정비 소요기간 & 추가 \\
\hline 10 & & 군내 정비능력 확보여부 & & 삭제 \\
\hline 11 & & 창급 정비기술 확보여부 & 창급 정비기술 확보여부 & \\
\hline 12 & 장비 잔여수명 & 장비 잔여수명 & & 삭제 \\
\hline 13 & & 장비가격(잔존가치) & & 추가 \\
\hline 14 & & 신규장비 여부 & & 임무 기여도 \\
\hline 15 & 장비운영 대수 & 장비운영 대수 &
\end{tabular}


이렇게 델파이 설문을 통해 선정한 지표에 대한 평가를 위해 전문가 의견을 수렴한 결과, 다음과 같은 결과가 도출되었다.

첫째, 각각의 지표는 설문 응답자의 전반적인 의견을 종합하여 중요도와 적합도가 평가되었으므 로 객관적 지표라고 할 수 있으며, 지표별 수준을 구분할 수 있어 정량화 시킬 수 있다.

둘째, 지표 중 장비 가동률, 보급 지연 불가동률, 부품 조달기간, 외주정비 소요 기간, 임무 기여 도(무기체계/전력지원체계)는 정확한 평가 값이 나오는 지표인 반면, 업체 참여 의지 및 능력, 예산 운용 적합성, 창급 정비기술 확보 여부는 조건에 따라서 그 수준에 대한 평가값이 주관적으로 평가 될 수 있는 지표이므로 적용 기준이 명확해야 한다.

특히, 성과기반군수(PBL) 사업의 특성을 고려 시 사업의 범위, 예산의 규모에 따라서 업체 참여 의지는 변화할 수 있으며, 수리 부속 재고 보유분에 대한 업체 재판매 조건, 최소 재고량 보유 수준 설정, 성과금 규모 등에 따라 예산 운용 적합성의 수준이 달라질 수 있으며, 창급 정비기술 확보는 어떤 부품 단위까지 기술을 확보할 것인가 하는 범위에 따라 다른 평가가 나올 수 있는 부분이다. 따라서, 실제로 이러한 정성적인 평가 지표를 적용을 할 때는 소요군이 지표에 대한 평가를 하기 전에 사업의 규모, 재고수준의 결정, 성과금 설정, 기술 확보 범위 등을 사전에 결정 한 후 결정된 수준에 따라 평가를 해야 할 것이다.

본 연구에서는 이러한 정성적 지표들은 각 소요군이 이러한 조건들을 충분히 고려하여 결정할 수 있다는 전제하에 핵심 지표로서 활용하였다.

\section{3 컨조인트 기법을 활용한 요인의 수준별 효용성 분석}

컨조인트 분석은 Green \& Rao (1971)가 최초로 소개한 분석 방법으로 각 지표들이 가지는 다양 한 속성에 대한 상대적 중요도를 평가하고, 각 속성 수준의 효용도(Utility)를 측정하는 기법이다.

컨조인트 분석을 위해서는 응답자들에게 다양한 속성을 가진 프로파일(카드)을 제공하고, 그 선 호도를 평가하는 과정이 필요한데 각각의 프로파일별로 선호도를 묻되 점수로 측정하는 방법 (rate-based conjoint)과 선호도를 순위로 측정하는 방법(rank-based conjoint)이 많이 사용되어 왔 다(Kim, 2014a, 2014b). 그러나, 너무 많은 프로파일이 생성되는 경우 응답자들이 선택하는 데 부담 을 느끼고 일관성 있는 답변을 하지 못하는 문제점이 있어, 이를 보완하기 위해 몇 개의 프로파일 을 묶어서 선택집합을 구성한 후 그 집단에 속한 프로파일 중에서 선호하는 프로파일을 선택하는 선택기반 컨조인트 분석(CBCA: choice based conjoint design)을 사용하기도 한다.

본 연구에서는 컨조인트 분석에 기반하여 핵심 요인별 수준에 대한 효용도 순위를 산출하였다. 앞선 성과기반군수(PBL) 적합 핵심 요인에 대한 델파이 설문조사 분석 결과 총 8개의 지표가 적합 성이 있는 것으로 나타났다. 또한, 8 개 지표는 아래의 <표 8>과 같이 각각 $2 \sim 3$ 개의 속성으로 구분 할 수 있는데 각 속성의 수준은 실제 운영데이터를 활용하였고, 일부는 정성적 기준을 적용하였다. 
<표 8> 속성별 가용한 수준

\begin{tabular}{|c|c|c|c|c|c|c|c|}
\hline 속성 & 가용한 수준 & 속성 & 가용한 수준 & 속성 & 가용한 수준 & 속성 & 가용한 수준 \\
\hline \multirow{3}{*}{$\begin{array}{l}\text { 장비 } \\
\text { 가동률 }\end{array}$} & $\begin{array}{l}\text { 지상 } 90 \% \text { 미만 } \\
\text { 해상 } 65 \% \text { 미만 } \\
\text { 항공 } 75 \% \text { 미만 }\end{array}$ & \multirow{3}{*}{$\begin{array}{l}\text { 수리부속 } \\
\text { 조달기간 }\end{array}$} & 150 일 이상 & \multirow{3}{*}{$\begin{array}{c}\text { 업체참여 } \\
\text { 능력 및 } \\
\text { 의지 }\end{array}$} & 높음 & \multirow{3}{*}{$\begin{array}{c}\text { 창급 } \\
\text { 정비기술 } \\
\text { 확보 } \\
\text { 가능성 }\end{array}$} & 거의 불가능 \\
\hline & $\begin{array}{l}\text { 지상 } 90 \sim 95 \% \\
\text { 해상 } 65 \sim 70 \% \\
\text { 항공 } 75 \sim 80 \%\end{array}$ & & $\begin{array}{l}90 \text { 일 이상 } \\
150 \text { 일미만 }\end{array}$ & & 중립적 & & 일부분 가능 \\
\hline & $\begin{array}{l}\text { 지상 } 95 \% \text { 이상 } \\
\text { 해상 } 70 \% \text { 이상 } \\
\text { 항공 } 80 \% \text { 이상 }\end{array}$ & & 90일 미만 & & 낮음 & & 대부분 가능 \\
\hline \multirow{3}{*}{$\begin{array}{l}\text { 보급지연 } \\
\text { 불가동률 }\end{array}$} & $\begin{array}{l}\text { 지상 } 7 \% \text { 이상 } \\
\text { 해상 } 20 \% \text { 이상 } \\
\text { 항공 } 10 \% \text { 이상 }\end{array}$ & \multirow{3}{*}{$\begin{array}{c}\text { 외주 } \\
\text { 정비기간 }\end{array}$} & 150일 이상 & \multirow{3}{*}{$\begin{array}{c}\text { 예산 절감 } \\
\text { 가능성 }\end{array}$} & 낮음 & \multirow{3}{*}{$\begin{array}{r}\text { 임무 } \\
\text { 기여도 }\end{array}$} & 무기체계 \\
\hline & $\begin{array}{c}\text { 지상 } 5 \sim 7 \% \\
\text { 해상 } 17 \sim 20 \% \\
\text { 항공 } 7 \sim 10 \%\end{array}$ & & $\begin{array}{l}\text { 90일 이상 } \\
150 \text { 일 미만 }\end{array}$ & & \multirow{2}{*}{ 높음 } & & \multirow{2}{*}{ 전력지원체계 } \\
\hline & $\begin{array}{l}\text { 지상 } 5 \% \text { 미만 } \\
\text { 해상 } 17 \% \text { 미만 } \\
\text { 항공 } 7 \% \text { 미만 }\end{array}$ & & 90일 미만 & & & & \\
\hline
\end{tabular}

<표 9> 컨조인트 분석 대안 카드

\begin{tabular}{|c|c|c|c|c|c|c|c|c|}
\hline \multirow{2}{*}{ 평가지표 } & \multicolumn{5}{|c|}{ 장비종류(분석용) } & \multicolumn{3}{|c|}{ 장비종류(검정용) } \\
\hline & 1 & 2 & 3 & .. & 27 & 28 & . & 31 \\
\hline 장비가동률 & $75 \%$ 미만 & $80 \%$ 이상 & $75 \sim 80 \%$ & . & $75 \sim 80 \%$ & 75\%미만 & . & $7 \overline{75 \sim 80 \%}$ \\
\hline $\begin{array}{l}\text { 보급지연 } \\
\text { 불가동률 }\end{array}$ & $7 \%$ 이상 & $5 \%$ 미만 & $5 \sim 7 \%$ & .. & $7 \%$ 이상 & $5 \%$ 미만 & . & $5 \%$ 미만 \\
\hline $\begin{array}{l}\text { 업체 참여 } \\
\text { 의지/능력 }\end{array}$ & 낮음 & 높음 & 중립 & .. & 낮음 & 높음 & . & 높음 \\
\hline $\begin{array}{l}\text { 예산운용 } \\
\text { 적합성 }\end{array}$ & 높음 & 높음 & 낮음 & .. & 높음 & 높음 & . & 낮음 \\
\hline $\begin{array}{l}\text { 수리부속 } \\
\text { 조달기간 }\end{array}$ & $\begin{array}{c}90 \sim \\
150 \text { 일 }\end{array}$ & $\begin{array}{l}90 \text { 일 } \\
\text { 미만 }\end{array}$ & $\begin{array}{c}90 \sim \\
150 \text { 일 }\end{array}$ & . . & $\begin{array}{c}150 \text { 일 } \\
\text { 이상 }\end{array}$ & $\begin{array}{c}90 \sim \\
150 \text { 일 }\end{array}$ & . & $\begin{array}{l}90 \text { 일 } \\
\text { 미만 }\end{array}$ \\
\hline $\begin{array}{l}\text { 외주정비 } \\
\text { 소요기간 } \\
\end{array}$ & $\begin{array}{l}90 \sim \\
150 \text { 일 }\end{array}$ & $\begin{array}{c}150 \text { 일 } \\
\text { 이상 }\end{array}$ & $\begin{array}{c}150 \text { 일 } \\
\text { 이상 }\end{array}$ & $\ldots$ & $\begin{array}{c}90 \sim \\
150 \text { 일 } \\
\end{array}$ & $\begin{array}{l}90 \text { 일 } \\
\text { 미만 }\end{array}$ & . & $\begin{array}{c}150 \text { 일 } \\
\text { 이상 }\end{array}$ \\
\hline $\begin{array}{c}\text { 창급 } \\
\text { 정비기술 } \\
\text { 확보 여부 }\end{array}$ & $\begin{array}{l}\text { 대부분 } \\
\text { 가능 }\end{array}$ & $\begin{array}{c}\text { 거의 } \\
\text { 불가능 }\end{array}$ & $\begin{array}{c}\text { 거의 } \\
\text { 불가능 }\end{array}$ & & $\begin{array}{l}\text { 일부분 } \\
\text { 가능 }\end{array}$ & $\begin{array}{c}\text { 거의 } \\
\text { 불가능 }\end{array}$ & . & $\begin{array}{l}\text { 일부분 } \\
\text { 가능 }\end{array}$ \\
\hline 임무기여도 & 전력지원 & $\begin{array}{c}\text { 전력지원 } \\
\text { 체계 }\end{array}$ & 무기체계 & .. & 무기체계 & 무기체계 & . & $\begin{array}{c}\text { 전력지원 } \\
\text { 체계 }\end{array}$ \\
\hline $\begin{array}{l}\mathrm{PBL} \text { 적용 } \\
\text { 우선순위 }\end{array}$ & 7 & 3 & 23 & .. & 12 & 1 & . & 4 \\
\hline
\end{tabular}


IBM SPSS statistic v23프로그램을 활용한 컨조인트 대안 카드 생성 결과 <표 9>과 같이 총 27 개가 생성되어 응답자들의 선호도 순을 모두 일관성 있게 답하기 어려운 문제가 발생하였다.

본 연구에서는 이런 문제를 해결하기 위해 설문자별로 우선순위가 중위에 속한 10 번부터 18 번 카드는 응답의 일관성을 유지하는 데 어려움이 있고 변별력도 낮다는 점에서 제외하고, 우선순위가 높은 9개 카드와 우선순위가 낮은 하위 9 개 카드를 선택적으로 분석하는 방법으로 접근하였다.

\section{$\mathrm{IV}$. 분석결과}

상위 9 개 카드에 대한 선택적 컨조인트 설문에 대한 분석 결과, 그 결과는 아래의 <표 $10>$ 와 같 이 도출할 수 있었다.

<표 10> 컨조인트 분석 결과(상위카드)

\begin{tabular}{|c|c|c|c|c|c|c|c|c|c|}
\hline \multicolumn{2}{|c|}{ 구분 } & $\begin{array}{c}\text { 가동률 } \\
75 \% \\
\text { 미만 }\end{array}$ & $\begin{array}{c}\text { 보급 } \\
\text { 불가동률 } \\
7 \% \text { 이상 }\end{array}$ & $\begin{array}{l}\text { 업체의지 } \\
\text { 능력 높음 }\end{array}$ & $\begin{array}{l}\text { 예산절감 } \\
\text { 기대높음 }\end{array}$ & $\begin{array}{c}\text { 부품 } \\
\text { 조달기간 } \\
150 \text { 일 이상 }\end{array}$ & $\begin{array}{c}\text { 외주 } \\
\text { 정비기간 } \\
150 \text { 일 이상 }\end{array}$ & $\begin{array}{l}\text { 창정비 기술 } \\
\text { 확보 가능성 } \\
\text { 거의없음 }\end{array}$ & $\begin{array}{c}\text { 임무 } \\
\text { 기여도 } \\
\text { 높음 }\end{array}$ \\
\hline \multirow{2}{*}{\multicolumn{2}{|c|}{$\begin{array}{c}\text { 델파이 } \\
\text { 지표별 가중치 }\end{array}$}} & 4.53 & 4.4 & 4.15 & 4.08 & 3.78 & 3.5 & 3.73 & 3.8 \\
\hline & & 1위 & 2위 & 3위 & 4위 & 6위 & 8위 & 7위 & 5위 \\
\hline \multirow{6}{*}{$\begin{array}{l}\text { 컨조인트 } \\
\text { 분석 } \\
\text { 갯수 }\end{array}$} & 1순위 & 4 & 1 & 0 & 1 & 0 & 0 & 4 & 6 \\
\hline & 2순위 & 1 & 1 & 0 & 6 & 0 & 0 & 1 & 7 \\
\hline & 3순위 & 5 & 1 & 0 & 8 & 0 & 0 & 1 & 1 \\
\hline & 4순위 & 1 & 3 & 1 & 0 & 2 & 5 & 2 & 2 \\
\hline & 5순위 & 2 & 0 & 2 & 0 & 5 & 3 & 3 & 0 \\
\hline & 합계 & 13 & 6 & 3 & 15 & 7 & 8 & 11 & 16 \\
\hline \multirow{2}{*}{\multicolumn{2}{|c|}{$\begin{array}{c}\text { 컨조인트 } \\
\text { 환산점수 } \\
\text { (순위간 } 10 \% \\
\text { 가중치 부여) }\end{array}$}} & 72.48 & 31.68 & 12.87 & 76.7 & 27.22 & 29.75 & 49.61 & 79.42 \\
\hline & & 3위 & 5위 & 8위 & 2위 & 7위 & 6위 & 4위 & 1위 \\
\hline
\end{tabular}

컨조인트 대안 카드 중 성과기반군수(PBL) 적용이 필요한 순서를 설문한 결과 임무 기여도가 높 은 무기체계를 1순위로 선택한 응답자가 6명으로 가장 많았으며, 가동률 $75 \%$ 미만인 경우를 1순위 로 포함한 응답자와 창정비 기술 확보 가능성이 거의 없는 경우를 1순위로 선택한 응답자가 각각 4명씩으로 높게 나왔다. 그러나, 2순위부터 5순위까지 포함하여 선택한 응답자가 가장 많은 대안은 임무 기여도가 높은 장비와 예산 절감 기대가 높은 장비, 가동률 $75 \%$ 미만인 장비 순으로 나타났 다. 이러한 결과를 바탕으로 각 요인의 수준별 컨조인트 환산점수를 계산할 수 있었으며, 위 <표 10> 는 우선순위 간 가중치를 $10 \%$ 로 설정하였을 때의 결과를 보여주고 있다. 컨조인트 환산점수는 요 
인 수준 간 상대적인 효용도를 나타내는 정도이므로, 우선순위 간 가중치 크기에 따라 그 값이 변 할 수 있기 때문에 순위 간 가중치에 따른 민감도 분석을 실시하였다.

<표 11> 민감도 분석결과

\begin{tabular}{c|c|c|c|c|c|c|c|c}
\hline $\begin{array}{c}\text { 순위별 } \\
\text { 가중치 }\end{array}$ & 가동률 & $\begin{array}{c}\text { 보급 } \\
\text { 불가동률 }\end{array}$ & 업체의지능력 & 예산절감 & 부품조달기간 & 외주정비기간 & $\begin{array}{c}\text { 창정비 } \\
\text { 기술확보 }\end{array}$ & $\begin{array}{c}\text { 임무 } \\
\text { 기여도 }\end{array}$ \\
\hline \hline $10 \%$ & 72.48 & 31.68 & 76.7 & 76.7 & 27.22 & 29.75 & 49.61 & 79.42 \\
\hline $20 \%$ & 86.07 & 36.96 & 92.21 & 92.21 & 27.97 & 31.5 & 58.19 & 98.04 \\
\hline $30 \%$ & 99.66 & 42.24 & 107.71 & 107.71 & 28.73 & 33.25 & 66.77 & 116.66 \\
\hline $40 \%$ & 113.25 & 47.52 & 123.22 & 123.22 & 29.48 & 35 & 75.35 & 135.28 \\
\hline $50 \%$ & 126.84 & 52.8 & 138.72 & 138.72 & 30.24 & 36.75 & 83.93 & 153.9 \\
\hline $60 \%$ & 140.43 & 58.08 & 154.22 & 154.22 & 31 & 38.5 & 92.5 & 172.52 \\
\hline $70 \%$ & 154.02 & 63.36 & 169.73 & 169.73 & 31.75 & 40.25 & 101.08 & 191.14 \\
\hline $80 \%$ & 167.61 & 68.64 & 185.23 & 185.23 & 32.51 & 42 & 109.66 & 209.76 \\
\hline $90 \%$ & 181.2 & 73.92 & 200.74 & 200.74 & 33.26 & 43.75 & 118.24 & 228.38 \\
\hline $100 \%$ & 194.79 & 79.2 & 216.24 & 216.24 & 34.02 & 45.5 & 126.82 & 247 \\
\hline
\end{tabular}

<그림 1 >에서 볼 수 있듯이 순위별 가중치에 따른 민감도 분석 결과 가중치의 크기가 효용도의 순위에 미치는 영향은 없는 것으로 나타났다.

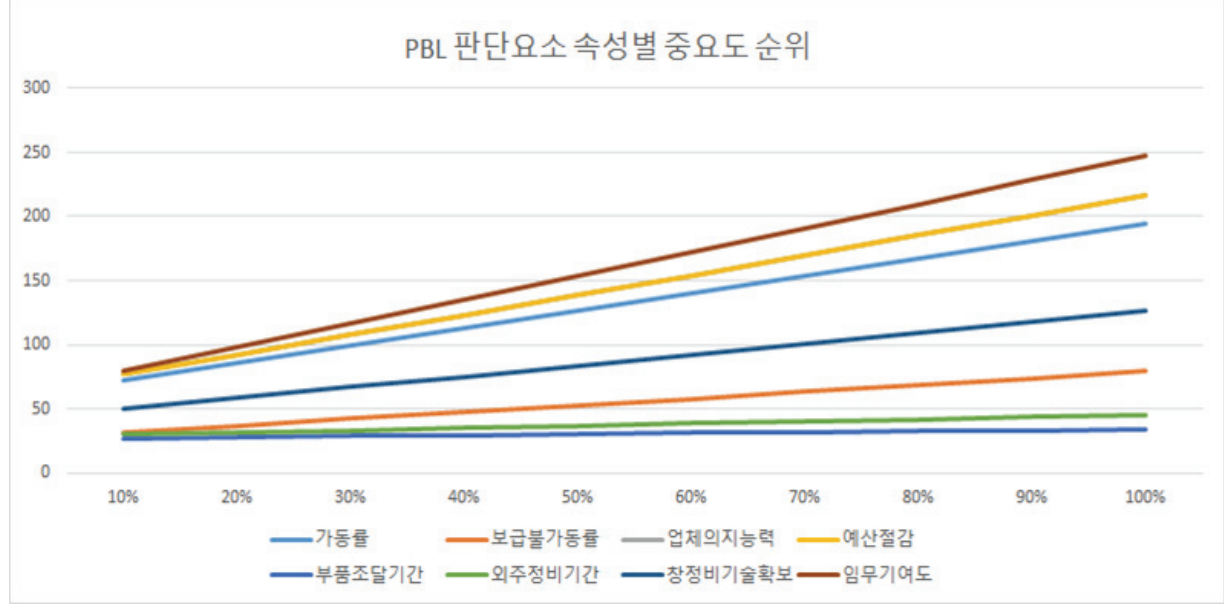

<그림 1> 우선순위순 민감도 분석 결과

다음으로는 하위 9 개 카드에 대한 컨조인트 설문에 대한 분석 결과, 그 결과는 아래의 <표 $12>$ 와 같이 도출할 수 있었다. 
<표 12> 컨조인트 분석결과(하위카드)

\begin{tabular}{|c|c|c|c|c|c|c|c|c|c|}
\hline & & $\begin{array}{c}\text { 가동률 } \\
80 \% \text { 이상 }\end{array}$ & $\begin{array}{l}\text { 보급 } \\
\text { 불가동률 } \\
5 \% \text { 미만 }\end{array}$ & $\begin{array}{c}\text { 업체 } \\
\text { 의지능력 } \\
\text { 낮음 }\end{array}$ & $\begin{array}{l}\text { 예산절감 } \\
\text { 기대 } \\
\text { 낮음 }\end{array}$ & $\begin{array}{c}\text { 부품 } \\
\text { 조달기간 } \\
90 \text { 일 미만 }\end{array}$ & $\begin{array}{c}\text { 외주 } \\
\text { 정비기간 } \\
90 \text { 일 미만 }\end{array}$ & $\begin{array}{l}\text { 창정비 } \\
\text { 기술 } \\
\text { 대부분 } \\
\text { 확보가능 } \\
\end{array}$ & $\begin{array}{l}\text { 임무 } \\
\text { 기여도 } \\
\text { 낮음 }\end{array}$ \\
\hline \multirow{2}{*}{\multicolumn{2}{|c|}{$\begin{array}{c}\text { 델파이 } \\
\text { 지표별 가중치 }\end{array}$}} & 4.53 & 4.4 & 4.15 & 4.08 & 3.78 & 3.5 & 3.73 & 3.8 \\
\hline & & 1위 & 2위 & 3위 & 4위 & 6위 & 8위 & 7위 & 5위 \\
\hline \multirow{6}{*}{$\begin{array}{c}\text { 컨조인트 } \\
\text { 분석 } \\
\text { 갯수 }\end{array}$} & 1순위 & 5 & 1 & 1 & 1 & 0 & 0 & 4 & 4 \\
\hline & 2순위 & 3 & 0 & 1 & 0 & 2 & 2 & 6 & 2 \\
\hline & 3순위 & 5 & 1 & 0 & 2 & 3 & 3 & 1 & 1 \\
\hline & 4순위 & 1 & 3 & 2 & 4 & 4 & 3 & 1 & 0 \\
\hline & 5순위 & 1 & 5 & 1 & 1 & 2 & 3 & 2 & 1 \\
\hline & 합계 & 15 & 10 & 5 & 8 & 11 & 11 & 14 & 8 \\
\hline \multirow{2}{*}{\multicolumn{2}{|c|}{$\begin{array}{c}\text { 환산점수 } \\
\text { (순위간 } 10 \% \\
\text { 가중치 부여) }\end{array}$}} & 86.07 & 47.96 & 24.49 & 37.54 & 47.63 & 43.75 & 66.02 & 39.52 \\
\hline & & 1위 & 3위 & 8위 & 7위 & 4위 & 5위 & 2위 & 6위 \\
\hline
\end{tabular}

컨조인트 대안카드 중 성과기반군수(PBL) 적용이 불필요한 순서를 설문한 결과 가동률 $80 \%$ 이 상을 1 순위로 선택한 응답자가 5 명으로 가장 많았으며, 창정비 기술 확보가 대부분 가능한 경우를 1 순위로, 임무 기여도가 낮은 경우를 1순위로 포함한 응답자가 각각 4명씩으로 높게 나왔다.

그러나, 2순위부터 5순위까지 포함하여 선택한 응답자가 가장 많은 대안은 가동률 $80 \%$ 이상인 경우에 이어서 창정비 기술확보 대부분 가능한 경우와 부품 조달/외주정비 기간 90 일 미만으로 나 타났다. 이러한 결과를 바탕으로 각 요인의 수준별 컨조인트 환산점수를 계산할 수 있었으며, 위 <표 12>은 우선순위 간 가중치를 $10 \%$ 로 설정하였을 때의 결과를 보여주고 있다. 컨조인트 환산점 수는 요인 수준 간 상대적인 효용도를 나타내는 정도이므로, 우선순위 간 가중치 크기에 따라 그 값이 변할 수 있어서 순위간 가중치에 따른 민감도 분석을 실시하였다.

<그림 2>에서 볼 수 있듯이 순위별 가중치에 따른 민감도 분석 결과 가중치의 크기가 효용도의 순위에 미치는 영향은 임무 기여도가 낮은 경우에만 가중치 $30 \%$ 를 전후하여 발생하고 있으나, 다 른 요소는 영향이 없는 것으로 나타났다. 효용도 순위에 대한 민감도 분석 결과 상위 8개 수준과 하위 8 개 수준에서 가중치에 따른 변화는 '임무기여도 낮음' 경우를 제외하고는 없었기 때문에, 분 석에 따라 나온 순위를 그대로 사용하고, '임무기여도 낮음'은 전체 효용도 순위를 선정하기 위하여 가중치 $10 \%$ 수준에서의 순위인 하위 6 번째인 17 위를 우선 적용하였다. 다만, 가중치를 $30 \%$ 이상으 로 할 경우에 '임무기여도 낮음'의 속성이 하위 5 위에서 하위 3 위로 변화하였는데 순위의 변화가 크지 않기 때문에 이 경우를 고려한 가중치별 효용도 우선순위 변화가 본 연구의 결과에 미치는 영향은 매우 낮다고 판단하였다. 
<표 13> 민감도 분석결과

\begin{tabular}{c|c|c|c|c|c|c|c|c}
\hline $\begin{array}{c}\text { 순위별 } \\
\text { 가중치 }\end{array}$ & 가동률 & $\begin{array}{c}\text { 보급 } \\
\text { 불가동률 }\end{array}$ & $\begin{array}{c}\text { 업체의지 } \\
\text { 능력 }\end{array}$ & 예산 절감 & $\begin{array}{c}\text { 부품 } \\
\text { 조달기간 }\end{array}$ & $\begin{array}{c}\text { 외주 } \\
\text { 정비기간 }\end{array}$ & $\begin{array}{c}\text { 창정비 } \\
\text { 기술확보 }\end{array}$ & $\begin{array}{c}\text { 임무 } \\
\text { 기여도 }\end{array}$ \\
\hline \hline $10 \%$ & 86.07 & 47.96 & 24.49 & 37.54 & 47.63 & 43.75 & 66.02 & 39.52 \\
\hline $20 \%$ & 104.19 & 51.92 & 28.22 & 42.43 & 53.68 & 49 & 79.82 & 48.64 \\
\hline $30 \%$ & 122.31 & 55.88 & 31.96 & 47.33 & 59.72 & 54.25 & 93.62 & 57.76 \\
\hline $40 \%$ & 140.43 & 59.84 & 35.69 & 52.22 & 65.77 & 59.5 & 107.42 & 66.88 \\
\hline $50 \%$ & 158.55 & 63.8 & 39.43 & 57.12 & 71.82 & 64.75 & 121.23 & 76 \\
\hline $60 \%$ & 176.67 & 67.76 & 43.16 & 62.02 & 77.87 & 70 & 135.03 & 85.12 \\
\hline $70 \%$ & 194.79 & 71.72 & 46.9 & 66.91 & 83.92 & 75.25 & 148.83 & 94.24 \\
\hline $80 \%$ & 212.91 & 75.68 & 50.63 & 71.81 & 89.96 & 80.5 & 162.63 & 103.36 \\
\hline $90 \%$ & 231.03 & 79.64 & 54.37 & 76.7 & 96.01 & 85.75 & 176.43 & 112.48 \\
\hline $100 \%$ & 249.15 & 83.6 & 58.1 & 81.6 & 102.06 & 91 & 190.23 & 121.6 \\
\hline
\end{tabular}

PBL 판단요소 속성별 중요도 역순위

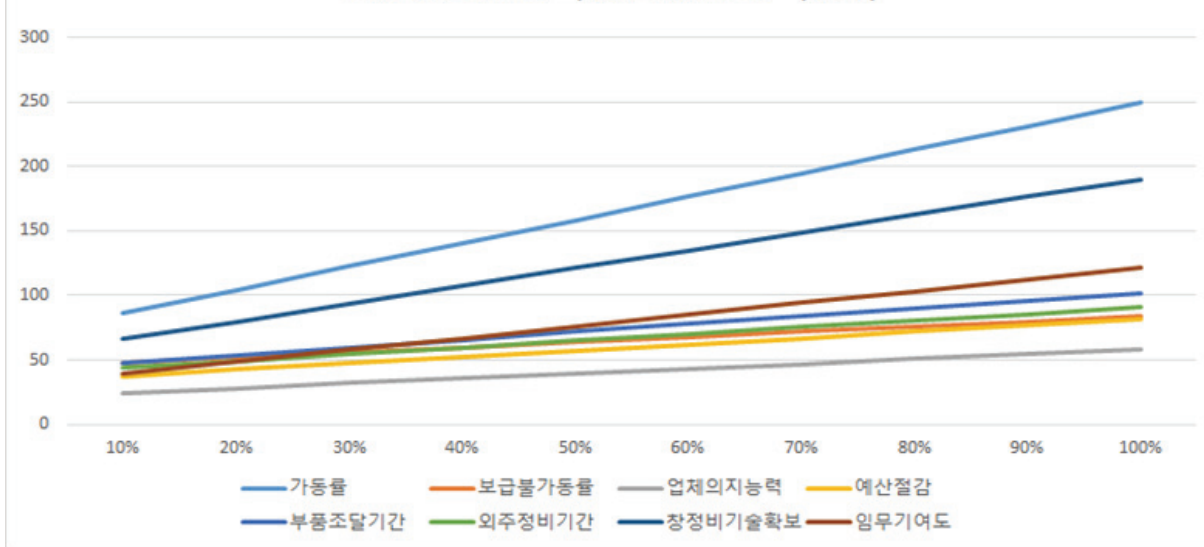

<그림 2> 우선순위순 민감도 분석 결과

위의 상위 9 개 카드와 하위 9 개 카드에 대한 효용도 우선순위를 종합한 결과 <표 $14>$ 과 같은 결과를 얻을 수 있었다. 총 22 개의 속성 중에 순위가 명확히 정해진 16 개 카드 외 6 개 카드는 중간 순위에 속하는 속성으로 해당 지표 내 효용도 순위의 평균값으로 추정하여 선택하였다.

각 속성에 대한 가중치는 효용도 순위에 따라 정률적으로 부여하였는데, 이는 최종적으로 성과 기반군수(PBL) 적용 적합 장비에 대한 판단요인에 대한 상대적인 수준을 구하기 위해서이다. 가중 치는 중윗값인 11,12 위를 기준점인 1 점으로 하여 순위별로 0.1 점씩 증감시켜 최대 2.0 , 최소 0 점으 로 구성하였다. 
<표 14> 컨조인트 분석결과 종합

\begin{tabular}{|c|c|c|c|c|c|c|c|}
\hline 지표 & 가용한 수준 (속성) & 효용도 순위 & 가중치 & 지표 & $\begin{array}{c}\text { 가용한 수준 } \\
\text { (속성) }\end{array}$ & 효용도 순위 & 가중치 \\
\hline \multirow{3}{*}{$\begin{array}{c}\text { 장비 } \\
\text { 가동률 }\end{array}$} & $\begin{array}{l}\text { 지상 } 90 \% \text { 미만 } \\
\text { 해상 } 65 \% \text { 미만 } \\
\text { 항공 } 75 \% \text { 미만 }\end{array}$ & 3 & 1.8 & \multirow{3}{*}{$\begin{array}{l}\text { 수리부속 } \\
\text { 조달기간 }\end{array}$} & 150일 이상 & 7 & 1.4 \\
\hline & $\begin{array}{l}\text { 지상 } 90 \sim 95 \% \\
\text { 해상 } 65 \sim 70 \% \\
\text { 항공 } 75 \sim 80 \%\end{array}$ & 9 & 1.2 & & $\begin{array}{l}90 \text { 일 이상 } \\
150 \text { 일미만 }\end{array}$ & 13 & 0.9 \\
\hline & $\begin{array}{l}\text { 지상 } 95 \% \text { 이상 } \\
\text { 해상 } 70 \% \text { 이상 } \\
\text { 항공 } 80 \% \text { 이상 }\end{array}$ & 22 & 0 & & 90일 미만 & 19 & 0.3 \\
\hline \multirow{3}{*}{$\begin{array}{l}\text { 보급지연 } \\
\text { 불가동률 }\end{array}$} & $\begin{array}{l}\text { 지상 } 7 \% \text { 이상 } \\
\text { 해상 } 20 \% \text { 이상 } \\
\text { 항공 } 10 \% \text { 이상 }\end{array}$ & 5 & 1.6 & \multirow{3}{*}{$\begin{array}{c}\text { 외주 } \\
\text { 정비기간 }\end{array}$} & 150일 이상 & 6 & 1.5 \\
\hline & $\begin{array}{c}\text { 지상 } 5 \sim 7 \% \\
\text { 해상 } 17 \sim 20 \% \\
\text { 항공 } 7 \sim 10 \%\end{array}$ & 10 & 1.1 & & $\begin{array}{l}\text { 90일 이상 } \\
150 \text { 일 미만 }\end{array}$ & 12 & 1.0 \\
\hline & $\begin{array}{l}\text { 지상 } 5 \% \text { 미만 } \\
\text { 해상 } 17 \% \text { 미만 } \\
\text { 항공 } 7 \% \text { 미만 }\end{array}$ & 20 & 0.2 & & 90일 미만 & 18 & 0.4 \\
\hline \multirow{3}{*}{$\begin{array}{c}\text { 업체참여 } \\
\text { 능력 및 } \\
\text { 의지 }\end{array}$} & 높음 & 8 & 1.3 & \multirow{3}{*}{$\begin{array}{c}\text { 창급 } \\
\text { 정비기술 } \\
\text { 확보 } \\
\text { 가능성 }\end{array}$} & 거의 불가능 & 4 & 1.7 \\
\hline & 중립적 & 11 & 1.0 & & 일부분 가능 & 14 & 0.8 \\
\hline & 낮음 & 15 & 0.7 & & 대부분 가능 & 21 & 0.1 \\
\hline \multirow{2}{*}{$\begin{array}{c}\text { 예산 절감 } \\
\text { 가능성 }\end{array}$} & 높음 & 2 & 1.9 & \multirow{2}{*}{$\begin{array}{r}\text { 임무 } \\
\text { 기여도 } \\
\end{array}$} & 무기체계 & 1 & 2.0 \\
\hline & 낮음 & 16 & 0.6 & & 전력지원체계 & 17 & 0.5 \\
\hline
\end{tabular}

본 연구에서 제시하려고 한 성과기반군수(PBL) 적용 적합성 판단 수리모형은 최종적으로 델파 이 분석을 통한 지표의 중요도와 컨조인트 분석을 통한 각 수준별 가중치를 종합한 결과 아래와 같으며, 각각의 지표별, 속성별 가중치는 <표 $15>$ 와 같다.

$Z_{i}=\sum_{i=1}^{8} x_{i} y_{i}, Z=$ 해당 $(i)$ 장비의 $P B L$ 적합성 점수, $x_{i}=$ 지표 가중치, $y_{i}=$ 속성 가중치 
<표 15> 성과기반군수(PBL) 적합 판단요인 지표 및 속성별 가중치

\begin{tabular}{|c|c|c|c|c|c|c|c|}
\hline $\begin{array}{l}\text { 판단요인 } \\
\text { (지표) }\end{array}$ & $\begin{array}{c}\text { 지표 } \\
\text { 가중치 }\end{array}$ & 가용한 수준 (속성) & $\begin{array}{l}\text { 속성 } \\
\text { 가중치 }\end{array}$ & $\begin{array}{l}\text { 판단요인 } \\
\text { (지표) }\end{array}$ & $\begin{array}{c}\text { 지표 } \\
\text { 가중치 }\end{array}$ & 가용한 수준 (속성) & $\begin{array}{l}\text { 속성 } \\
\text { 가중치 }\end{array}$ \\
\hline \multirow{3}{*}{ 장비 가동률 } & \multirow{3}{*}{4.53} & $\begin{array}{l}\text { 지상 } 90 \% \text { 미만 } \\
\text { 해상 } 65 \% \text { 미만 } \\
\text { 항공 } 75 \% \text { 미만 }\end{array}$ & 1.8 & \multirow{3}{*}{$\begin{array}{l}\text { 수리부속 } \\
\text { 조달기간 }\end{array}$} & \multirow{3}{*}{3.78} & 150일 이상 & 1.4 \\
\hline & & $\begin{array}{l}\text { 지상 } 90 \sim 95 \% \\
\text { 해상 } 65 \sim 70 \% \\
\text { 항공 } 75 \sim 80 \%\end{array}$ & 1.2 & & & $\begin{array}{l}90 \text { 일 이상 } \\
150 \text { 일미만 }\end{array}$ & 0.9 \\
\hline & & $\begin{array}{l}\text { 지상 } 95 \% \text { 이상 } \\
\text { 해상 } 70 \% \text { 이상 } \\
\text { 항공 } 80 \% \text { 이상 }\end{array}$ & 0 & & & 90일 미만 & 0.3 \\
\hline \multirow{3}{*}{$\begin{array}{l}\text { 보급지연 } \\
\text { 불가동률 }\end{array}$} & \multirow{3}{*}{4.40} & $\begin{array}{l}\text { 지상 } 7 \% \text { 이상 } \\
\text { 해상 } 20 \% \text { 이상 } \\
\text { 항공 } 10 \% \text { 이상 }\end{array}$ & 1.6 & \multirow{3}{*}{$\begin{array}{c}\text { 외주 } \\
\text { 정비기간 }\end{array}$} & \multirow{3}{*}{3.50} & 150 일 이상 & 1.5 \\
\hline & & $\begin{array}{c}\text { 지상 } 5 \sim 7 \% \\
\text { 해상 } 17 \sim 20 \% \\
\text { 항공 } 7 \sim 10 \%\end{array}$ & 1.1 & & & $\begin{array}{l}\text { 90일 이상 } \\
150 \text { 일 미만 }\end{array}$ & 1.0 \\
\hline & & $\begin{array}{l}\text { 지상 } 5 \% \text { 미만 } \\
\text { 해상 } 17 \% \text { 미만 } \\
\text { 항공 } 7 \% \text { 미만 }\end{array}$ & 0.2 & & & 90일 미만 & 0.4 \\
\hline \multirow{3}{*}{$\begin{array}{l}\text { 업체참여 } \\
\text { 능력/의지 }\end{array}$} & \multirow{3}{*}{4.15} & 높음 & 1.3 & \multirow{3}{*}{$\begin{array}{c}\text { 창급 } \\
\text { 정비기술 } \\
\text { 확보가능성 }\end{array}$} & \multirow{3}{*}{3.73} & 거의 불가능 & 1.7 \\
\hline & & 중립적 & 1.0 & & & 일부분 가능 & 0.8 \\
\hline & & 낮음 & 0.7 & & & 대부분 가능 & 0.1 \\
\hline \multirow{2}{*}{$\begin{array}{l}\text { 예산절감 } \\
\text { 가능성 }\end{array}$} & \multirow{2}{*}{4.08} & 높음 & 1.9 & \multirow{2}{*}{ 임무 기여도 } & \multirow{2}{*}{3.80} & 무기체계 & 2.0 \\
\hline & & 낮음 & 0.6 & & & 전력지원체계 & 0.5 \\
\hline
\end{tabular}

성과기반군수 $(\mathrm{PBL})$ 적용 적합성을 판단하기 위해서는 중간값을 기준으로 설정하는 것이 필요한 데, 이를 $\mathrm{PBL}$ 적합성 중간값이라고 명칭하고, 아래와 같이 값을 구하였다.

※ $\mathrm{PBL}$ 적합성 중간값 $=4.53 \times 1.2+4.40 \times 1.1+4.15 \times 1.0+4.08 \times 1.25+3.78 \times 0.9$

$$
+3.5 \times 1+3.73 \times 0.8+3.8 \times 1.25=34.162
$$

<표 16> PBL 적합성 판단 기준점수(모든 지표 적용시)

\begin{tabular}{c|c|c|c}
\hline 구분 & 평균 Level 이상 & 평균 Level(중간값) & 평균 Level 미만 \\
\hline \hline 총 점수기준 & 34.162점 이상 & 34.162점 & 34.162 점 미만 \\
\hline 검토순위 & 중점 검토대상 & 차 순위 검토대상 & 적용 보류 \\
\hline
\end{tabular}

위 계산식에 따른 평균 수준은 지표 가중치와 속성 가중치 중간값을 곱한 합으로, 계산 결과 
34.162점으로 계산되었다. 즉, 어떤 장비를 본 연구에서 제시한 수리모형에 따라 평가한 결괏값이 34.162점 이상이면 성과기반군수(PBL) 적용이 상대적으로 필요하다고 판단할 수 있으며, 그 미만 이면 필요성이 상대적으로 낮다고 판단할 수 있겠다.

위 판단 기준점수는 8개의 모든 지표를 평가하였을 때를 기준으로 산출하였다. 그러나 앞서 논의 한 사항 중 정성적인 지표에 대한 판단 기준이 명확하지 않을 때는 정량적인 지표만을 가지고 평가 해야 할 상황이 발생할 수 있다. 따라서 정성적 지표인 업체 참여의지/능력, 예산 절감 가능성, 창급 정비기술 확보 가능성을 제외한 정량적인 지표만을 가지고 수리모형을 구성하여 기준점수를 산출 하면 아래와 같은 결과를 도출할 수 있다.

※ $\mathrm{PBL}$ 적합성 기준값: 정량적 요소별 가중치 $\times$ 속성별 중간값의 합계

$$
\begin{aligned}
& =4.53 \times 1.2+4.40 \times 1.1+3.78 \times 0.9+3.5 \times 1.0+3.8 \times 1.25 \\
& =21.928
\end{aligned}
$$

<표 17> PBL 적합성 판단 기준점수(정량적 지표만 적용시)

\begin{tabular}{c|c|c|c}
\hline 구분 & 평균 Level 이상 & 평균 Level(중간값) & 평균 Level 미만 \\
\hline \hline 총 점수기준 & 21.928 점 이상 & 21.928 점 & 21.928 점 미만 \\
\hline 검토순위 & 중점 검토대상 & 적용 기준선 & 차순위 검토 \\
\hline
\end{tabular}

위의 <표 $17>$ 은 정량적인 지표만 적용한 기준을 나타낸 표이다. 즉, 총 8 개의 지표 중 정책 결정 과정에 선택적으로 활용될 필요성이 있는 지표만을 가지고 별도의 기준을 구하는 것도 가능하겠다.

\section{$\mathrm{V}$. 수리모형에 대한 검증}

앞서 델파이 기법으로 도출한 핵심 지표에 컨조인트 분석으로 도출한 수준별 가중치에 따라 최 종적으로 수리모형을 구성하였는데, 이렇게 이론적으로 완성한 수리모형이 실제로 효용성이 있는 지를 검증하기 위해 다음의 절차를 수행하였다.

우선, 실제 공군이 성과기반군수(PBL)를 적용하고 있는 장비를 본 수리모형에 적용하였을 때, 기준값으로 제시한 34.162점 이상이 나올 것인지, 그 반대로 성과기반군수(PBL) 적용이 불필요한 장비를 위 수리모형에 대입하여 계산하였을 때 34.162점 이하가 나올 것인지를 평가하였는데, 그 결과는 아래 <표 18>에서 확인할 수 있다. 
A study on the key factors of suitability for performance-based logistics using ... / Inseob Hong • Sukjae Jeong 63

<표 18> PBL 적용중인 장비에 대한 평가(모든지표 적용시)

\begin{tabular}{c|c|c|c|c|c}
\hline \multirow{2}{*}{$\begin{array}{c}\text { 판단요인 } \\
\text { (지표) }\end{array}$} & 지표 & \multicolumn{4}{|c}{ 장비별 평가점수 } \\
\cline { 3 - 6 } & 가중치 & $\mathrm{A}$ & $\mathrm{B}$ & $\mathrm{C}$ & $\mathrm{D}$ \\
\hline \hline 장비 가동률 & 4.53 & 5.436 & 5.436 & 5.436 & 0 \\
\hline 보급지연 불가동률 & 4.40 & 7.04 & 4.84 & 0.88 & 7.04 \\
\hline 업체참여 의지/능력 & 4.15 & 5.395 & 4.15 & 4.15 & 5.395 \\
\hline 예산절감 가능성 & 4.08 & 7.752 & 5.712 & 5.712 & 7.752 \\
\hline 수리부속 조달기간 & 3.78 & 5.292 & 5.292 & 5.292 & 5.292 \\
\hline 외주 정비기간 & 3.50 & 5.25 & 5.25 & 5.25 & 5.25 \\
\hline $\begin{array}{c}\text { 창급 정비기술 } \\
\text { 확보가능성 }\end{array}$ & 3.73 & 2.984 & 0.373 & 0.373 & 6.341 \\
\hline 임무 기여도 & 3.80 & 7.6 & 7.6 & 7.6 & 7.6 \\
\hline 합계 & - & 46.749 & 38.653 & 34.693 & 44.67 \\
\hline
\end{tabular}

$\mathrm{A}$ 에서 $\mathrm{D}$ 까지의 장비는 현재 공군이 성과기반군수(PBL)을 적용하고 있는 무기체계를 나타내고 있 는데, 군의 운용자료를 기반으로 하였으므로 정확한 무기체예명 대신 알파벳 기호를 사용하였으며, 판단요인(지표)에 대한 평가 시점은 성과기반군수(PBL) 사업을 적용하기 전을 기준으로 하였다.

정성지표인 업체 참여 의지/능력, 예산 절감 가능성, 창급 정비기술 확보 가능성은 현 성과기반 군수(PBL) 사업의 범위 및 계약 내용을 근거로 작성하였다.

평가 결과 4개 장비 모두 기준점수인 34.162점을 초과하고 있으며, 본 연구에서 제시한 수리모형 이 성과기반군수(PBL) 적용 적합성 평가에 유효하다는 결과를 확인할 수 있었다.

또한, 정량적 지표만을 가지고 평가하였을 때의 결과는 아래 <표 $19>$ 과 같으며, 이 경우에도 4 개 장비 모두 기준점수인 21.928점을 초과하고 있다.

<표 19> PBL 적용중인 장비에 대한 평가(정량적 지표 적용시)

\begin{tabular}{c|c|c|c|c|c}
\hline \multirow{2}{*}{$\begin{array}{c}\text { 판단요인 } \\
\text { (지표) }\end{array}$} & 지표 & \multicolumn{4}{|c}{ 장비별 평가점수 } \\
\cline { 3 - 6 } & 가중치 & $\mathrm{A}$ & $\mathrm{B}$ & $\mathrm{C}$ & $\mathrm{D}$ \\
\hline \hline 장비 가동률 & 4.53 & 5.436 & 5.436 & 5.436 & 0 \\
\hline 보급지연 불가동률 & 4.40 & 7.04 & 4.84 & 0.88 & 7.04 \\
\hline 수리부속 조달기간 & 3.78 & 5.292 & 5.292 & 5.292 & 5.292 \\
\hline 외주 정비기간 & 3.50 & 5.25 & 5.25 & 5.25 & 5.25 \\
\hline 임무 기여도 & 3.80 & 7.6 & 7.6 & 7.6 & 7.6 \\
\hline 합계 & - & 30.618 & 28.418 & 24.458 & 25.182 \\
\hline
\end{tabular}

다음은 성과기반군수(PBL)을 적용하지 않고도 원활하게 운용하고 있는 장비로 전력지원체계 기 
동장비(00톤 트럭), 전력지원체계 통신장비(A 무전기), 항공무기체계(B 항공기), 기동무기체계(항 공기 지원 차량 $\mathrm{X}$ )를 평가하였다. 각각의 장비에 대하여 평가한 결과, <표 20>와 같이 모두 34.162 점 미만의 결괏값을 도출하였다.

<표 20> PBL 적용 불필요 장비에 대한 평가(모든지표 적용시)

\begin{tabular}{|c|c|c|c|c|c|}
\hline \multirow{2}{*}{$\begin{array}{l}\text { 판단요인 } \\
\text { (지표) }\end{array}$} & \multirow{2}{*}{$\begin{array}{l}\text { 지표 } \\
\text { 가중치 }\end{array}$} & \multicolumn{4}{|c|}{ 장비별 평가점수 } \\
\hline & & 00톤 트럭 & $\mathrm{A}$ 무전기 & $\mathrm{B}$ 항공기 & $\begin{array}{c}\text { 항공기 } \\
\text { 지원차량 X }\end{array}$ \\
\hline 장비 가동률 & 4.53 & 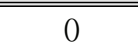 & 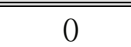 & 5.436 & 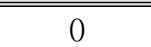 \\
\hline 보급지연 불가동률 & 4.40 & 0.88 & 0.88 & 0.88 & 0.88 \\
\hline 업체참여 능력/의지 & 4.15 & 5.395 & 4.15 & 2.905 & 2.905 \\
\hline 예산절감 가능성 & 4.08 & 2.448 & 2.448 & 2.448 & 2.448 \\
\hline 수리부속 조달기간 & 3.78 & 1.134 & 5.292 & 3.402 & 3.402 \\
\hline 외주 정비기간 & 3.50 & 1.4 & 5.25 & 3.5 & 3.5 \\
\hline 창급정비기술 확보가능성 & 3.73 & 0.373 & 6.341 & 0.373 & 2.984 \\
\hline 임무 기여도 & 3.80 & 1.9 & 1.9 & 7.6 & 7.6 \\
\hline 합계 & - & 13.53 & 26.261 & 26.544 & 23.719 \\
\hline
\end{tabular}

또한, 정량적 지표로 분석한 결과도 <표 $21>$ 과 같이 4 개 장비가 모두 21.928 점 미만으로 성과기 반군수(PBL) 적용이 상대적으로 불필요하다는 결론을 도출하였다. 다만, $\mathrm{B}$ 항공기의 경우 성과기 반군수(PBL)를 적용하지 않고도 원활하게 운영하는 장비임에도 평가점수는 20.818점으로 기준점 수에 매우 근접한 결과를 보여주고 있는데, 이는 성과기반군수(PBL)가 항공 장비에 매우 적합한 제도라는 점을 보여주는 결과라고도 할 수 있겠다. 즉, $\mathrm{B}$ 항공기의 경우는 성과기반군수 $(\mathrm{PBL})$ 를 적용 시 현재보다 더 나은 성과를 낼 가능성이 있겠다.

<표 21> PBL 적용 불필요 장비에 대한 평가(정량적 지표 적용시)

\begin{tabular}{c|c|c|c|c|c}
\hline \multirow{2}{*}{$\begin{array}{c}\text { 판단요인 } \\
\text { (지표) }\end{array}$} & \multirow{2}{*}{$\begin{array}{c}\text { 지표 } \\
\text { 가중치 }\end{array}$} & \multirow{2}{*}{ 00톤 트럭 } & \multirow{2}{*}{$\mathrm{A}$ 무전기 } & $\mathrm{B}$ 항공기 & $\begin{array}{c}\text { 항공기 } \\
\text { 지원차량 X }\end{array}$ \\
\cline { 5 - 6 } & & 0 & 0 & 5.436 & 0 \\
\hline \hline 장비 가동률 & 4.53 & 0.88 & 0.88 & 0.88 & 0.88 \\
\hline 보급지연 불가동률 & 4.40 & 1.134 & 5.292 & 3.402 & 3.402 \\
\hline 수리부속 조달기간 & 3.78 & 1.4 & 5.25 & 3.5 & 3.5 \\
\hline 외주 정비기간 & 3.50 & 1.9 & 1.9 & 7.6 & 7.6 \\
\hline 임무 기여도 & 3.80 & 5.314 & 13.322 & 20.818 & 15.382 \\
\hline 합계 & - & & & &
\end{tabular}


결론적으로는 본 연구에서 제시한 수리모형은 모든지표를 평가하였을 때나 정량적인 지표만으 로 평가하였을 때 모두 성과기반군수(PBL) 적용 적합성 평가에 유효한 결과를 도출하였으므로, 수 리모형으로서 타당성을 검증받았다고 평가할 수 있겠다.

\section{VI. 결론 및 논의}

본 연구에서는 성과기반군수(PBL) 적용이 적합한 장비를 판단하기 위한 핵심 요인과 그 요인의 수준별 가중치를 도출하여 종합적인 판단을 할 수 있는 수리모형을 제시하고자 하였다. 이를 위해 관련 업무를 직간접적으로 수행한 전문가 집단을 대상으로 델파이 설문을 실시하여 핵심 요인을 선정하고, 중요도(가중치) 및 적합도를 평가하였다. 이렇게 선정된 8개의 핵심 요인(지표)을 2 3개 의 수준으로 나누고, 컨조인트 기법을 바탕으로 대안 카드를 생성 후 3 차 설문을 통해 응답자가 선 택한 유효한 상위 카드와 하위 카드를 분석하여 수준별 효용도 순위를 선정하였다.

이렇게 선정된 순위에 따라 상대적 가중치를 부여하였고, 델파이 설문으로 분석한 판단요인(지 표)별 중요도(가중치)를 복합하여, 성과기반군수(PBL) 적용 적합성 판단 수리모형을 제시하였다. 이때, 기준이 되는 중간값으로 모든 지표를 적용하였을 때는 34.162점을, 정성적 지표를 제외하고 적용하였을 때는 21.928 점을 제시하였고, 성과기반군수(PBL) 적용 판단 시 해당 장비의 평가 값이 중간값이 넘는 경우 상대적으로 성과기반군수 $(\mathrm{PBL})$ 적용이 필요하며, 중간값 미만이면 상대적으로 성과기반군수 $(\mathrm{PBL})$ 적용이 불필요하다는 점을 보여주었다.

본 연구를 통해 기존에 국방부 성과기반군수(PBL) 적용 기준을 다음 두 가지 측면에서 개선하였다 는 점에서 의의가 있다고 볼 수 있다. 첫째, 평가지표를 전문가의 의견을 통해 정량적, 객관적으로 보 완하였다. 기존 6 개 지표에서 불필요한 2 개 지표(부품단가상승률, 장비 잔여 수명)를 삭제하였고, 추 가로 필요한 3 개 지표(임무 기여도, 예산 운용 적합성, 업체 참여 의지 및 능력)를 보강하여 총 8개 지표로 개선하였다. 둘째, 성과기반군수(PBL) 적용을 위한 적합성 판단 기준 수리모형을 좀 더 객관 적으로 보완하였다. 기존에는 요인 수준 간 동일한 척도와 정도로 가중치를 부여하고, 합계를 구하여 적용 Level을 제시했다면, 본 연구는 판단 요인(지표)의 중요도(가중치)와 수준별 효용도 순에 따른 가중치를 제시하여 좀 더 객관적인 수리모형을 제시하였다. 이를 향후 각 군에서 성과기반군수(PBL) 적용 필요성을 일차적으로 판단할 때 기준으로 활용할 수 있다는 점에서 가치가 있다고 할 것이다.

\section{Acknowledgements}

We would like to thank Editage (www.editage.co.kr) for English language editing.

\section{Declaration of Conflicting Interests}

The author(s) declared no potential conflicts of interest with respect to the research, authorship, and/or publication of this article. 


\section{Reference}

Green, P. E., \& Rao, V. R. (1971). Conjoint Measurement for Quantifying Judgmental Data. Journal of Marketing Research, 8(3), 355. https://doi.org/10.2307/3149575

LAWSHE, C. H. (1975). A QUANTITATIVE APPROACH TO CONTENT VALIDITY. Personnel Psychology, 28(4), 563 - 575. https://doi.org/10.1111/j.1744-6570.1975.tb01393.x

Kim, Bu-Yong. (2014b). An Empirical Comparison of Predictability of Ranking-based and Choice-based Conjoint Analysis. Korean Journal of Applied Statistics, 27(5), 681 - 691. https://doi.org/10.5351/kjas.2014.27.5.681

Kim, Bu-Yong. (2014a). New Method for Preference Measurement in Ranking-based Conjoint Analysis. Korean Journal of Applied Statistics, 27(2), 185 - 195. https://doi.org/10.5351/kjas.2014.27.2.185

KUMAR, U. D., NOWICKI, D., RAMÍREZ-MÁRQUEZ, J. E., \& VERMA, D. (2007). A GOAL PROGRAMMING MODEL FOR OPTIMIZING RELIABILITY, MAINTAINABILITY AND SUPPORTABILITY UNDER PERFORMANCE BASED LOGISTICS. International Journal of Reliability, Quality and Safety Engineering, 14(03), 251 - 261. https://doi.org/10.1142/s0218539307002623

국방부 훈령 제2061호, 성과기반군수지원 훈령(2017.8.17.)

미 국방성 (2016). Performance Based Logistics (PBL) Guidebook.

https://www.dau.edu/tools/t/Performance-Based-Logistics-(PBL)-Guidebook 국방부 홈페이지. “www.mnd.go.kr” 2020 


\section{다기준 의사결정 방법을 활용한 성과기반군수 적합성 핵심요인 연구*}

홍인섭** - 정석재***

한국군은 변화하는 대내외 환경에 적응하고 효율적인 국방운영을 위하여 2008년에 민간기업이 군 장비의 운영유지를 책임지는 성과기반군수지원(PBL) 제도를 도입하여 사업을 확대해 왔으며, 그 결과 부품 조달 및 정비기간 단축으로 장비 가동률을 향상시키고 보유 재고를 감축하여 비용을 절감하는 효과를 달성하였다. 이 러한 성과를 토대로 국방부는 $\mathrm{PBL}$ 사업을 확대해 가는 정책을 추진하고 있으나, 적용대상 장비를 선정하는데 있어 객관적이고 타당한 기준이 부재하여 적용장비를 확대하는데 애로를 격고 있다. 따라서, 본 연구는 PBL 적용 적합장비에 대한 객관적 판단요소와 이를 정량화한 수치를 제공하여 향후 $\mathrm{PBL}$ 사업 선정의 기준을 제시 하는 것을 목표로 하였다. 분석방법으로 델파이 기법을 활용한 전문가 설문을 실시하였으며, 분석결과 $\mathrm{PBL}$ 적용을 위한 선정 핵심요인을 ‘장비가동률', '보급불가동률' '업체 참여의지/능력', '예산절감 가능성', '부품조달 기간', ‘외주정비기간', ‘창급 정비기술확보 가능성', ‘임무기여도'로 도출하였다. 이렇게 선정된 8개 핵심요인의 평가 수준을 정하고, 선택기반 컨조인트 방법에 따라 대안 카드별 우선순위를 정하는 3차 설문을 통하여 각 요인의 수준별 효용성을 산출하였다.

분석내용을 핵심적으로 풀어서 표현하자면 임무중요도가 높은 무기체계가 가동률이 $75 \%$ 미만으로 전투준 비태세가 낮은 상태에서 성과기반군수(PBL)을 적용 시 예산절감 효과를 기대할 수 있을 때 우선순위가 가장 높으며, 반대로 장비 가동률이 $80 \%$ 이상으로 운영 중이며, 창급정비기술을 대부분 확보하였거나 할 수 있으 며, 부품 보급에 따른 불가동이 $5 \%$ 미만이거나, 90 일 이내에 확보할 수 있다면 성과기반군수(PBL) 적용이 필 요하지 않다는 사실을 객관적 지표로 확인할 수 있었다. 본 연구는 객관적 데이터에 기반한 핵심요소와 수준 에 대한 효용도를 제시하였다는데 의의가 있으며, 향후 본 연구결과가 국방부 성과기반군수(PBL) 정책에 반 영되기를 기대한다.

주제어 : 성과기반군수지원, 가동률, 조달기간, 델파이 분석, 컨조인트 분석

* 이 논문은 2019년도 광운대학교 교내학술연구비 지원에 의해 연구되었음

** (제1저자) 광운대학교 방위사업학과 박사과정(공군본부, 군수참모부, 중령), inseobh@gmail.com *** (교신저자) 광운대학교 경영학부 교수, sjjeong@kw.ac.kr 
